\title{
Growth and cellular proliferation of pig corpora lutea throughout the oestrous cycle
}

\author{
W. A. Ricke ${ }^{1 *}$, D. A. Redmer ${ }^{1}$, and L. P. Reynolds ${ }^{1,2}$ \\ ${ }^{1}$ Department of Animal and Range Sciences and ${ }^{2}$ Cell Biology Center, Biotechnology Institute, \\ North Dakota State University, Fargo, North Dakota 58105-5727, USA
}

\begin{abstract}
Corpora lutea were obtained from gilts on days $2,4,8,12,15$ or 18 after oestrus. Luteal fresh masses and DNA contents increased linearly $(P<0.01)$ from day 2 to day 12 and day 2 to day 15, respectively. Changes in the ratio of protein:DNA were greatest between days 2 and 4 and days 15 and 18, whereas changes in DNA content were relatively small during the same intervals. Thus, a major component of changes in the size of the corpus luteum during the early and late periods of the luteal phase was cellular hypertrophy. Proliferation of luteal cells in vivo (nuclear incorporation of 5bromo-2-deoxyuridine, a thymidine analogue) was greatest on day 2 and decreased exponentially $(P<0.01)$ throughout the oestrous cycle. Results from co-localization of 5-bromo-2-deoxyuridine and factor VIII (von Willebrand factor), a marker of endothelial cells, or 5-bromo-2-deoxyuridine and $3 \beta$-hydroxysteroid dehydrogenase, a marker of steroidogenic cells, indicated that some of the luteal steroidogenic cells proliferated early in luteal development. However, during early and mid-cycle, most of the luteal cell proliferation occurred in the endothelial cells. Thus, during growth of the pig corpus luteum, which is extremely rapid, most of the proliferating luteal cells are vascular endothelial cells. This observation is consistent with the high vascularity and blood flow of the mature corpus luteum and implies a critical role for angiogenesis in luteal development in the pig, as has been proposed for several other mammalian species.
\end{abstract}

\section{Introduction}

The corpus luteum is essential for normal reproductive function in mammals as it is the primary source of circulating progesterone (Niswender and Nett, 1988; Reynolds et al., 1994; Reynolds and Redmer, 1999). The corpus luteum also is one of the fastest growing tissues in the adult (Niswender and Nett, 1988; Jablonka-Shariff et al., 1993; Reynolds et al., 1994). Thus, an improved understanding of the mechanisms regulating luteal growth is important not only because of its implications for regulation of fertility, but also because the corpus luteum makes an excellent model to study growth of normal adult tissues (Reynolds et al., 1994; Redmer and Reynolds, 1996; Reynolds and Redmer, 1998).

In domestic animals, it is thought that large luteal cells, which are presumably derived from the follicular granulosa, either do not proliferate or undergo minimal proliferation only at the beginning of the oestrous cycle (Moss et al.,1954; Priedkalns et al., 1968; McClellan et al., 1975; Jablonka-Shariff et al., 1993; Zheng et al., 1994). In contrast, small luteal cells and non-steroidogenic luteal cells, presumably derived from

*Present address: Department of Animal Science, University of Missouri, Columbia, MO 65201, USA.

${ }^{+}$Correspondence. the follicular theca, appear to proliferate much more rapidly throughout the oestrous cycle and even into early pregnancy (Priedkalns et al., 1968; McClellan et al., 1975; JablonkaShariff et al., 1993, 1997; Zheng et al., 1994; Reynolds et al., 1994; Redmer and Reynolds, 1996; Reynolds and Redmer, 1998, 1999).

Accompanying rapid growth of the corpus luteum, dynamic changes in luteal vascularity occur throughout the oestrous cycle (Clark, 1900; Andersen, 1926; Bassett, 1943; Bruce and Moor, 1976; Reynolds, 1986; Reynolds et al., 1992; Zheng et al., 1993). The mature corpus luteum is highly vascular and receives one of the greatest rates of blood flow, per unit of tissue mass, of any organ (Reynolds, 1986; Niswender and Nett, 1988; Reynolds et al., 1992, 1994; Redmer and Reynolds, 1996; Reynolds and Redmer, 1998, 1999). Conversely, decreased luteal vascularity is associated with inadequate luteal function and early embryonic loss (Hansel, 1981; Garverick and Smith, 1986; Niswender and Nett, 1988; Reynolds et al., 1994; Redmer and Reynolds, 1996; Reynolds and Redmer, 1998, 1999).

Although the patterns of growth, vascular development and cellular proliferation of the corpus luteum are well understood in several mammalian species, this information is not yet available for the corpus luteum of domestic pigs (Reynolds et al., 1994; Redmer and Reynolds, 1996; Reynolds 
and Redmer, 1998). Therefore, the objectives of this study were to evaluate luteal growth and development, as well as the relative rates of proliferation of the various types of luteal cell, throughout the oestrous cycle in pigs.

\section{Materials and Methods}

\section{Tissue collection}

Crossbred (Yorkshire $\times$ Duroc) gilts that had shown at least one oestrous cycle of normal duration (18-23 days) were randomly assigned to be killed on days $2,4,8,12,15$ or 18 of the oestrous cycle ( $n=6-8$ gilts per day). For each gilt, $10 \mathrm{ml}$ of blood was collected into a heparinized test tube via puncture of the vena cava (Reynolds and Ford, 1984) at $1 \mathrm{~h}$ before the animal was killed. After blood was drawn, each pig received an i.v. injection of 5-bromo-2-deoxyuridine (BrdU, $5 \mathrm{mg} \mathrm{kg}^{-1}$ body weight; Aldrich, Milwaukee, WI), a thymidine analogue (Jablonka-Shariff et al., 1993, 1994, 1997; Jin $e t$ al., 1994). After the animals were killed, the ovaries were removed and all corpora lutea from both ovaries $(n=$ $13.4 \pm 0.3$ corpora lutea per gilt) were dissected and weighed. For one gilt on day 15 after oestrus, a large $(1320 \mathrm{mg})$ fluidfilled corpus luteum was found, which was not analysed further and was not included in the data for this gilt. For each gilt, four corpora lutea were chosen at random and were fixed in Carnoy's solution (Jablonka-Shariff et al., 1992, 1994, 1997; Zheng et al., 1993; Jin et al., 1994); these corpora lutea were used for immunohistochemistry and analysis of the labelling index, as described below. Additional samples of all of the remaining corpora lutea were snap frozen on dry ice and stored at $-80^{\circ} \mathrm{C}$ until analysis of DNA, protein and progesterone contents. Thus, DNA, protein and progesterone analyses were conducted only on the remaining corpora lutea $(n=9.4 \pm 0.3$ per gilt) and not on those obtained for immunohistochemistry and labelling index.

\section{DNA and protein concentrations and contents}

DNA and protein concentrations of corpora lutea were determined as described by Reynolds et al. (1990), JablonkaShariff et al. (1993, 1997) and Zheng et al. (1994). Briefly, 100 $\mathrm{mg}$ of each corpus luteum was homogenized in 10 volumes of buffer containing $3 \mathrm{mmol} \mathrm{NaN}_{3} \mathrm{l}^{-1}$ and 1 mmol EDTA $\mathrm{l}^{-1}$ ( $\mathrm{pH}$ 7.2) using a Polytron (Brinkmann, Westbury, NY). Tissue homogenates were analysed for DNA concentration using the diphenylamine procedure and for protein concentration using the method of Lowry et al. (1951) (see also Reynolds et $a l ., 1990)$. Standards were DNA type I from calf thymus and BSA (fraction V), respectively (Sigma, St Louis, MO). Tissue DNA and protein contents were calculated by multiplying the concentrations by total luteal mass. The DNA content was used as an index of tissue hyperplasia, and the ratio of protein:DNA was used as an index of tissue hypertrophy (Baserga, 1985; Reynolds et al., 1990; Jablonka-Shariff et al., 1993, 1997; Jin et al., 1994; Zheng et al., 1994).

\section{Progesterone radioimmunoassays}

Progesterone concentrations were measured in benzene-hexane extracts of plasma by radioimmunoassay as previously validated by Taraska et al. (1989) and Redmer et al. (1991). The assay sensitivity $\left(90 \% B / B_{0}\right)$ was $25 \mathrm{pg}$ per tube. All samples were assayed in a single assay; the intraassay coefficient of variation was $4.5 \%$. The recovery of $\left[{ }^{3} \mathrm{H}\right]$ progesterone in extracted samples was $85.8 \%$, and progesterone concentrations in the extracts were adjusted for recovery.

Progesterone concentrations were also measured in benzene-hexane extracts of the luteal tissue homogenates using the same radioimmunoassay described above as reported by Jablonka-Shariff et al. (1993) and Zheng et al. (1994). All of the tissue homogenates were run in a single assay, and the intra-assay coefficient of variation was $5.2 \%$. Recovery of $\left[{ }^{3} \mathrm{H}\right]$ progesterone in extracted samples was $75.7 \%$, and progesterone concentrations in the extracts were adjusted for recovery. Luteal progesterone contents were calculated by multiplying the tissue concentrations by luteal fresh mass (Zheng et al., 1994).

\section{Immunohistochemistry (BrdU, BrdU and factor VIII, BrdU and $3 \beta-H S D$ )}

BrdU, a thymidine analogue that is incorporated into cellular DNA during the $S$ phase of the cell cycle, was immunolocalized in paraffin-wax-embedded tissue sections (5 $\mathrm{\mu m})$ using a specific BrdU antibody and the modified avidin-biotinylated peroxidase complex (ABC) method (Schutte et al., 1987; Jablonka-Shariff et al., 1992, 1993, 1997; Jin $e$ al., 1994) to visualize proliferating cells. Briefly, after 15 min treatment with $3 \%(\mathrm{v} / \mathrm{v}) \mathrm{H}_{2} \mathrm{O}_{2}$ in absolute methanol to quench endogenous peroxidase, followed by $30 \mathrm{~min}$ treatment with $2 \mathrm{~mol} \mathrm{HCl}^{-1}$ to denature nuclear chromatin, tissue sections were treated for $20 \mathrm{~min}$ with blocking buffer consisting of PBS $\left(0.01 \mathrm{~mol}\right.$ phosphate $\mathrm{l}^{-1}$ and $0.14 \mathrm{~mol} \mathrm{NaCl}$ $\mathrm{I}^{-1}, \mathrm{pH} 7.3$ ) containing $0.3 \%(\mathrm{v} / \mathrm{v})$ Triton-X100 (Mallinckrodt, Paris) and $1 \%(\mathrm{v} / \mathrm{v})$ normal horse serum (Vector Laboratories, Burlingame, CA).

Sections were incubated for $60 \mathrm{~min}$ at $22^{\circ} \mathrm{C}$ with a mouse monoclonal anti-BrdU antibody (Boehringer Mannheim, Indianapolis, IN; $1 \mathrm{mg} \mathrm{ml}^{-1}$ in blocking buffer). Control sections were incubated with normal horse serum (Vector Laboratories) or mouse ascites fluid (ICN Biochemicals, Costa Mesa, CA) in place of the primary antibody. Detection of the primary antibody was accomplished using a biotinylated secondary antibody (horse anti-mouse IgG; Vector Laboatories) and the $\mathrm{ABC}$ method (Vectastain; Vector Laboratories). The colour reaction was developed by incubating the sections for 3-4 min with a peroxidase substrate (SG; Vector Laboratories) that produces a grey-black colour. Tissue sections were rinsed twice in distilled $\mathrm{H}_{2} \mathrm{O}$ and counterstained briefly ( $10 \mathrm{~s}$ ) with Harris' haematoxylin (Luna, 1968; Jablonka-Shariff et al., 1992, 1993, 1997; Jin et al., 1994).

Paraffin-wax-embedded tissue sections were stained for BrdU and also for $3 \beta$-hydroxysteroid dehydrogenase ( $3 \beta$ HSD), the enzyme that catalyses the conversion of 
Table 1. Number, fresh masses, DNA content, and protein:DNA ratios of pig corpora lutea throughout the oestrous cycle

\begin{tabular}{lcccccc}
\hline & \multicolumn{5}{c}{ Day of the oestrous cycle } \\
\cline { 2 - 7 } & 2 & 4 & 8 & 12 & 15 & 18 \\
\hline $\begin{array}{l}\text { Number } \\
\text { Fresh mass (mg) }\end{array}$ & $13.1 \pm 0.7$ & $14.6 \pm 1.2$ & $13.9 \pm 0.8$ & $12.5 \pm 0.8$ & $13.6 \pm 0.7$ & $12.8 \pm 0.7$ \\
$\begin{array}{l}\text { DNA content } \\
\text { (mg per corpus luteum) }\end{array}$ & $134 \pm 5.1^{\mathrm{a}}$ & $336 \pm 73.9^{\mathrm{ab}}$ & $466 \pm 37.8^{\mathrm{ab}}$ & $525 \pm 37.5^{\mathrm{b}}$ & $513 \pm 34.3^{\mathrm{b}}$ & $228 \pm 31.0^{\mathrm{a}}$ \\
Protein:DNA & $0.40 \pm 0.04^{\mathrm{a}}$ & $0.58 \pm 0.01^{\mathrm{ab}}$ & $0.89 \pm 0.10^{\mathrm{bc}}$ & $0.92 \pm 0.11^{\mathrm{c}}$ & $1.20 \pm 0.18^{\mathrm{c}}$ & $1.00 \pm 0.12^{\mathrm{c}}$ \\
\hline
\end{tabular}

abc Within a row, means with different superscripts are significantly different $(P<0.05)$.

Values are the means \pm SE.

pregnenolone to progesterone (Gore-Langton and Armstrong, 1994; Conley et al., 1995) to evaluate proliferation of steroidogenic luteal cells. The first portion of this dual labelling consisted of staining for BrdU as described above. Subsequently, slides were incubated $\left(22^{\circ} \mathrm{C}\right)$ for $20 \mathrm{~min}$ in blocking buffer (PBS, Triton-X100 with 1-2\% (v/v) goat serum; Vector Laboratories), followed by incubation for 90 min at $22^{\circ} \mathrm{C}$ with a specific rabbit polyclonal antibody against 33-HSD (1:250 in blocking buffer; Oxygene, Dallas, TX) as reported by Conley et al. (1995). Control sections were incubated with normal rabbit serum (Vector Laboratories) in place of the $3 \beta-H S D$ primary antibody. Sections were rinsed twice in PBS and incubated with a biotinylated secondary antibody (goat anti-rabbit IgG; Vector Laboratories) for 30 min. After rinsing twice in PBS, sections were incubated with ABC complex (Vector) for $30 \mathrm{~min}$ and rinsed twice in PBS. The colour reaction was developed by incubating sections (3-4 min) in a second peroxidase substrate (AEC; Vector Laboratories), which produces a yellow-brown deposit.

Paraffin-wax-embedded tissue sections were stained for BrdU and for factor VIII (von Willebrand factor), which is a specific marker for endothelial cells (Shepro and D'Amore, 1984; Jablonka-Shariff et al., 1993; Zheng et al., 1993; Reynolds et al., 1994), to evaluate proliferation of endothelial cells. The first portion of this dual labelling was staining for BrdU as described above. Factor VIII was immunolocalized using a specific rabbit anti-human factor VIII antibody (Sigma) and indirect immunoperoxidase detection via the $\mathrm{ABC}$ method as reported by Reynolds et al. (1992), Jablonka-Shariff et al. (1993) and Zheng et al. (1993). For this procedure, factor VIII antibody (final dilution 1:100 in blocking buffer) was incubated with tissue sections for $30 \mathrm{~min}$ at $22^{\circ} \mathrm{C}$. Control staining consisted of replacing the factor VIII primary antibody with the same dilution of normal rabbit serum (Vector Laboratories). The factor VIII primary antibody was then visualized using the same procedures as described above for visualization of the $3 \beta$-HSD primary antibody, except that the peroxidase substrate used (VIP; Vector Laboratories) produces a purple deposit.

\section{Labelling index}

For each corpus luteum, seven randomly chosen fields were evaluated in a randomly chosen tissue section $(n=1-4$ corpora lutea per animal). The labelling index, which provides an index of the rate of cell proliferation, was calculated as the area of positively stained (BrdU-labelled) nuclei as a percentage of the total area stained (BrdU- plus haematoxylin stained) using an image analysis system (VIDAS v.2.5; Roche Image Analysis Systems, Elon College, NC) as reported by Jablonka-Shariff et al. (1993), Jin et al. (1994) and Fricke et al. (1997). It has been demonstrated that this procedure compares favourably with the use of tritiated thymidine for determining the labelling index in vivo (Jablonka-Shariff et al., 1993; Lin and Allison, 1993; Jin et al., 1994; Fricke et al., 1997).

\section{Statistical analysis}

Data were analysed using the general linear model (GLM) (SAS, 1985) analysis of variance; the day of the oestrous cycle was the main effect. When the $F$ test was significant $(P<0.05)$, differences among means were evaluated with Duncan's multiple-range test (SAS, 1985). In addition, linear and non-linear regression procedures were used to evaluate the relationships among the variables (SAS, 1985). Unless otherwise noted, the data are reported as means $\pm \mathrm{SE}$.

\section{Results}

The average numbers of corpora lutea per gilt did not vary across the stages of the oestrous cycle (Table 1). Fresh masses of corpora lutea increased $(P<0.01)$ linearly $(y=$ $135.8+37.2 x$; where $y$ is mass $(\mathrm{mg})$ and $x$ is day of the oestrous cycle; $r=0.93$ ) and by more than fourfold from day 2 to day 12 of the oestrous cycle (Table 1$)$. In contrast, luteal DNA contents increased $(P<0.01)$ linearly $(y=0.32+0.058 x$; $r=0.94$ ) from day 2 to day 15 (Table 1 ). Nevertheless, luteal fresh masses were highly correlated $(r=0.96 ; P<0.05)$ with luteal DNA contents. Changes in the size of luteal cells, as indicated by the ratio of protein:DNA, were greatest between days 2 and 4 and days 15 and 18 (Table 1), and these changes were also apparent histologically (Fig. 1). Although the size of the cells was smaller on day 2 compared with days 4-12, the cells appeared to be normal and healthy on the basis of their nuclear morphology (Fig. 1a). In contrast, on days 15 and 18 the cells were not only smaller but many of the nuclei 

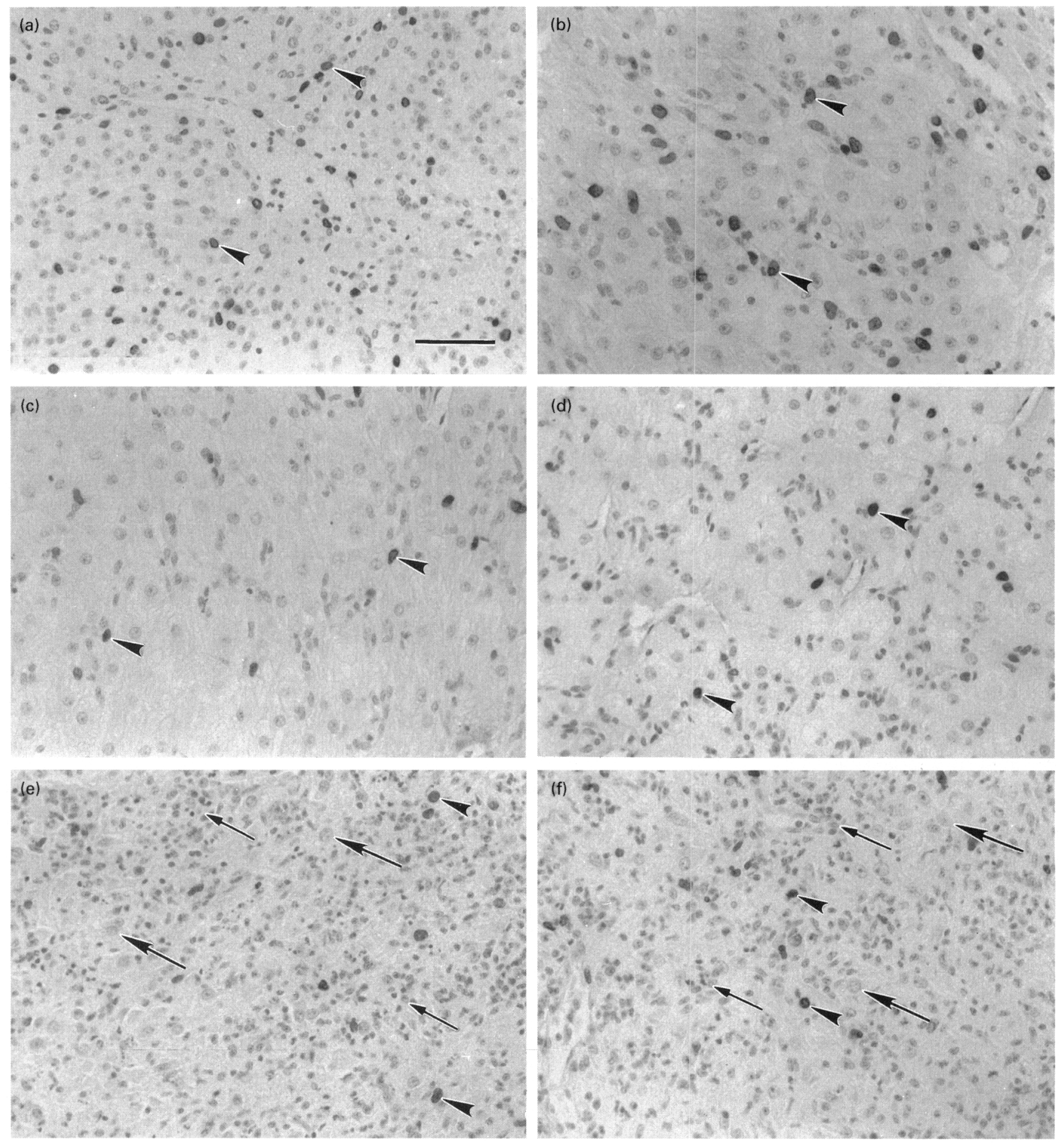

Fig. 1. Immunolocalization of 5-bromo-2-deoxyuridine (BrdU) in sections of corpora lutea from pigs on days 2 (a), 4 (b), 8 (c), 12 (d), 15 (e) and 18 (f) of the oestrous cycle. Two BrdU-labelled nuclei are indicated (arrowheads) in each field. Note the marked increase in the size of cells from day 2 to day $4(\mathrm{a}, \mathrm{b})$; also note on days 15 and $18(\mathrm{e}, \mathrm{f})$ the marked reduction in the size of cells as well as the 'pockets' of pyknotic nuclei (small arrows) dispersed among regions of apparently healthy cells (large arrows). Scale bar represents $50 \mu \mathrm{m}$.

appeared pyknotic, and 'pockets' of these pyknotic nuclei were dispersed among regions of apparently healthy cells (Fig. 1e,f). Luteal progesterone content and plasma progesterone concentrations followed a pattern similar to that of luteal masses (Table 2).

Immunohistochemical staining of pig corpora lutea for
BrdU showed that the relative rate of luteal cell proliferation (that is, the proportion of cells showing incorporation of BrdU into the nucleus) was greatest on days 2 and 4 of the oestrous cycle and was less on all of the other days (Fig. 1). These observations were in agreement with the quantitative evaluation of luteal labelling index, which was greatest 
Table 2. Luteal progesterone contents and plasma progesterone concentrations throughout the oestrous cycle in pigs

\begin{tabular}{lcccccc}
\hline & \multicolumn{6}{c}{ Day of the oestrous cycle } \\
\cline { 2 - 7 } & 2 & 4 & 8 & 12 & 15 & 18 \\
\hline $\begin{array}{l}\text { Luteal progesterone } \\
\text { (mg per corpus luteum) }\end{array}$ & $6.7 \pm 1.3^{\mathrm{a}}$ & $18.6 \pm 6.4^{\mathrm{b}}$ & $36.1 \pm 3.2^{\mathrm{bc}}$ & $52.1 \pm 4.1^{\mathrm{c}}$ & $27.4 \pm 10.4^{\mathrm{b}}$ & $1.0 \pm 0.3^{\mathrm{a}}$ \\
$\begin{array}{c}\text { Plasma progesterone } \\
\text { (ng ml }{ }^{-1} \text { ) }\end{array}$ & $5.0 \pm 1.6^{\mathrm{a}}$ & $21.6 \pm 2.0^{\mathrm{b}}$ & $33.2 \pm 2.7^{\mathrm{bc}}$ & $35.7^{2} \pm 2.7^{\mathrm{c}}$ & $22.8 \pm 7.2^{\mathrm{b}}$ & $0.7 \pm 0.2^{\mathrm{a}}$ \\
\hline
\end{tabular}

${ }^{\mathrm{abc}}$ Within a row, means with different superscripts are significantly different $(P<0.05)$.

Values are the means $\pm \mathrm{SE}$.

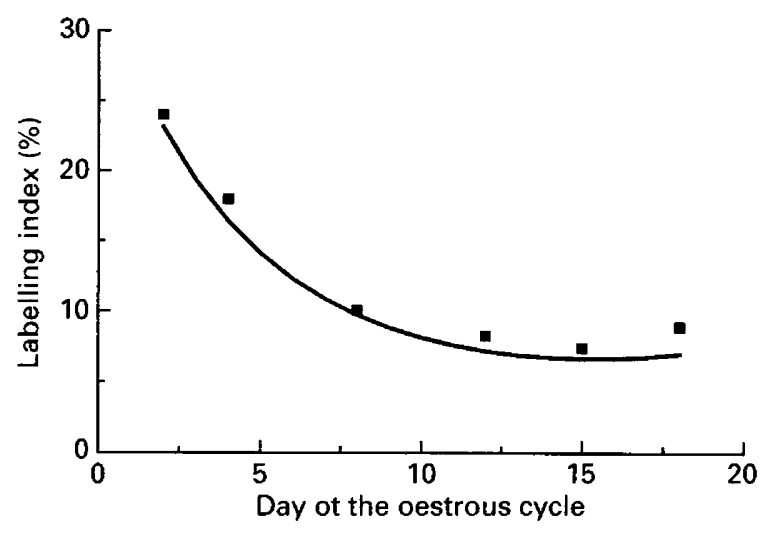

Fig. 2. Labelling index (LI) of pig corpora lutea throughout the oestrous cycle. These values are based on the area of 5-bromo-2deoxyuridine (BrdU)-labelled nuclei expressed as a percentage of the total stained area (haematoxylin + BrdU) for seven randomly chosen fields in each of four corpora lutea per gilt $(n=6-8$ gilts per day). The labelling index on days 2 and 4 was greater $(P<0.05)$ than on all other days. The labelling index decreased exponentially $(P<0.01)$ throughout the oestrous cycle (regression line: $L I=$ $34.51807 \mathrm{e}^{(-0.214008+0.006969 t) t}, r=0.70$, where $L I=$ the labelling index at any given time, $L I_{0}=$ the labelling index at time 0 , $k 1=$ the initial instantaneous growth rate (proportion per day), $k 2$ = the change in the instantaneous growth rate per unit of time, and $t=$ time in days). Pooled SEM $=2.23 \%$.

$(P<0.05)$ on days 2 and 4 of the oestrous cycle $(21.0 \pm 4.2 \%$; Fig. 2) but reduced thereafter $(8.6 \pm 1.1 \%$ across days $8-18)$. Overall, the decrease in labelling index throughout the oestrous cycle could be described $(P<0.01)$ by the exponential growth model (Jablonka-Shariff et al., 1993; Reynolds and Redmer, 1999):

$$
L I=L I_{0} \times \mathrm{e}^{(-k 1+k 2 \times t) t}
$$

where $L I=$ the labelling index at any given time, $L I_{0}=$ the labelling index at time $0, k 1=$ the initial instantaneous growth rate (proportion per day), $k 2=$ the change in the instantaneous growth rate per unit of time, and $t=$ time in days.

Factor VIII was present in the luteal tissues on all days of the oestrous cycle and was immunolocalized to the cytoplasm of the endothelial cells of the larger microvessels, as well as to those of the capillaries (Fig. 3). On day 2, localization was primarily in the larger microvessels within the connective tissue (presumably invading thecal) tracts (data not shown). By day 4 and continuing to day 15, factor VIII was localized in the capillaries throughout the luteal parenchyma as well as in the larger microvessels that were located primarily in the connective tissue tracts (Fig. 3a,b). In addition, during mid-cycle (days 4-15), endothelial cells formed a dense network surrounding the luteal parenchymal cells (Fig. 3a,b), thus, in the mature corpus luteum most of the parenchymal cells were in contact with one or more capillaries. However, by day 18, which represents the period of luteal regression, factor VIII expression was confined almost exclusively to the larger microvessels (Fig. 3c).

Dual staining for BrdU and factor VIII demonstrated that most (approximately $60-75 \%$ ) of the proliferating cells on days 2-4 of the oestrous cycle were endothelial cells (Fig. 3a). Thus, co-localization of BrdU and factor VIII was greatest early in the oestrous cycle. By mid-cycle, although many of the BrdU-labelled cells still appeared to be endothelial cells, an equal number of BrdU-labelled cells were negative for factor VIII (Fig. 3b). By day 18, most of the cell proliferation was in factor VIII-negative cells (Fig. 3c); when present, the BrdU-labelled endothelial cells were associated with the larger microvessels. However, only approximately one-third of the corpora lutea on day 18 showed cell proliferation, whereas cell proliferation in most of the day 18 corpora lutea was relatively low.

The steroidogenic enzyme $3 \beta-$ HSD was present in the luteal tissues on all days of the oestrous cycle and was localized to the cytoplasm of the luteal parenchymal cells (Fig. 4). On day 2, although 3 $\beta$-HSD was found throughout the luteal parenchyma, the concentrations were relatively low (data not shown). By day 4 , and continuing to day 15 , the intensity of $3 \beta-H S D$ staining remained relatively high (Fig. $4 b)$. By day 18 , the intensity of $3 \beta$-HSD staining had again decreased (Fig. 4c).

Dual staining for BrdU and $3 \beta-\mathrm{HSD}$ demonstrated that although relatively few of the BrdU-positive cells also expressed $3 \beta-\mathrm{HSD}$, most of the proliferating steroidogenic cells were present early in the oestrous cycle (Fig. 4a). By day 8 and thereafter, proliferating steroidogenic cells were observed only rarely (Fig. $4 \mathrm{~b}, \mathrm{c}$ ).

\section{Discussion}

The results of the present study demonstrate that the pig corpus luteum grows extremely rapidly and shows 


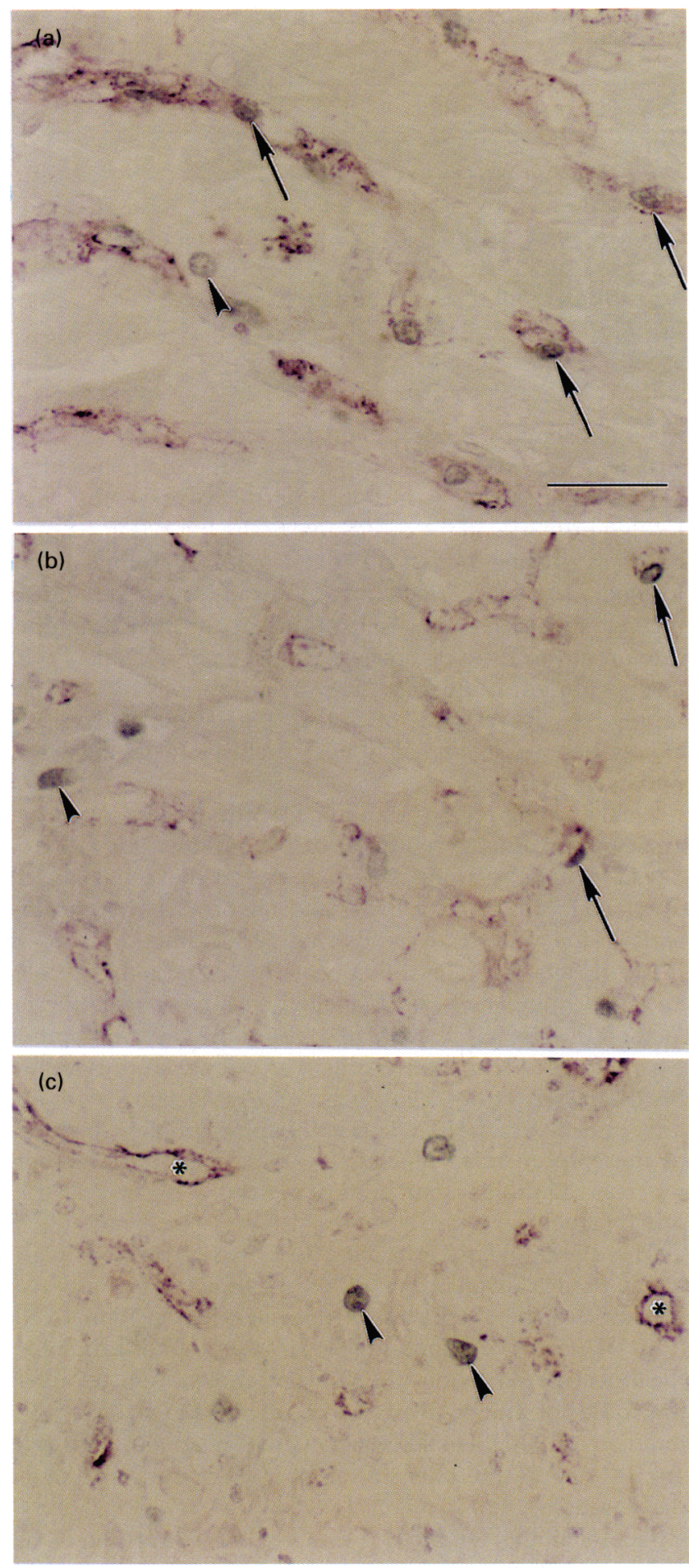

Fig. 3. Dual immunohistochemical staining for factor VIII (purple) and 5-bromo-2-deoxyuridine (BrdU) (grey-black) in sections of corpora lutea from pigs on days 4 (a), 12 (b) and 18 (c) of the oestrous cycle. Note the cytoplasmic labelling for factor VIII (purple), nuclear labelling for BrdU (arrowheads), and frequent dual labelling of cells (arrows); also note factor VIII staining of capillaries early in the oestrous cycle (a) and at mid-cycle (b), but primarily larger microvessels $\left(^{*}\right)$ late in the oestrous cycle. Scale bar represents $25 \mu \mathrm{m}$.
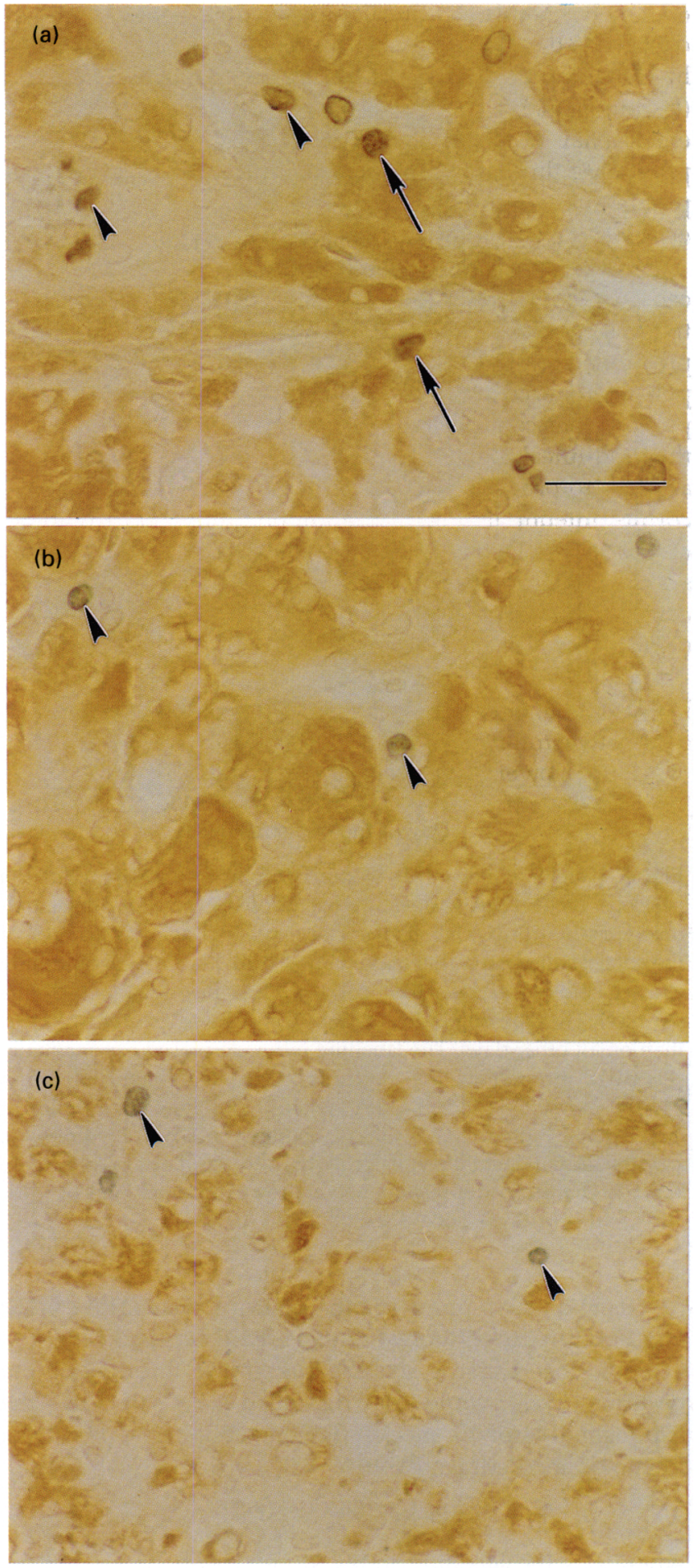

Fig. 4. Dual labelling for $3 \beta$-hydroxysteroid dehydrogenase $(3 \beta$ HSD) (yellow-brown) and 5-bromo-2-deoxyuridine BrdU (greyblack) in sections of corpora lutea from pigs on days 4 (a), 12 (b) and 18 (c) of the oestrous cycle. Note the cytoplasmic labelling for $3 \beta$ HSD (yellow-brown) and nuclear labelling for BrdU (arrowheads); some dual-labelled cells (arrows) are present early in the oestrous cycle (a) but none later in the oestrous cycle $(b, c)$. Scale bar represents $25 \mu \mathrm{m}$. 
extremely high rates of cellular proliferation from day 2 to day 12 of the oestrous cycle. The results of the immunohistochemistry show that although both parenchymal (steroidogenic) and non-parenchymal (that is, primarily endothelial cells, pericytes and fibroblasts) luteal cells proliferate throughout the oestrous cycle, most of the cell proliferation in corpora lutea at the early stage of the oestrous cycle occurs in the non-steroidogenic cells.

In this study, steroidogenic activity of luteal parenchymal cells was determined by measuring progesterone concentrations in plasma and luteal tissues. In agreement with previous reports (Masuda et al., 1966), the profile of plasma progesterone concentrations was similar to that of luteal progesterone content; there was an increase from the early to the mid-luteal phase. Thus, luteal progesterone content appears to provide a good index of normal function of the corpus luteum in pigs. In addition, luteal progesterone content was reflected by changes in the intensity of $3 \beta-H S D$ staining, which was least on days 2 and 18 and greatest on days $4-15$, in agreement with other studies of luteal 3 $\beta$-HSD (Conley et al., 1995).

On the basis of the linear increases in both luteal mass and DNA content, the doubling time for tissue mass or number of cells between days 2 and 12 was approximately 122-194 h, which is slower than that reported for sheep $(57-78 \mathrm{~h}$; Jablonka-Shariff et al., 1993). Nevertheless, the pig corpus luteum, as reported for other species, grows as fast as even the most aggressive tumours, such as Burkitt's lymphoma (Baserga, 1985; Jablonka-Shariff et al., 1993; Zheng et al., 1994; Christenson and Stouffer, 1996). The labelling index of the early corpus luteum also was high ( $24 \%$ ) compared with that of normal adult tissues, which is typically $<0.5 \%$. Therefore, the rates of growth and cellular proliferation of pig corpora lutea are comparable with those of the fastest growing tissues reported.

The data for luteal mass obtained in the present study are in agreement with previous reports by Cavazos et al. (1969) and Conley and Ford (1991). However, in addition, it was shown that between days 2 and 4 of the oestrous cycle, the marked increase in luteal fresh masses was accompanied by only a $45 \%$ increase in luteal DNA content. In contrast, during this same interval the luteal protein:DNA ratio increased by more than twofold. Thus, the early growth of the pig corpus luteum is associated primarily with cellular hypertrophy (that is, an increase in the size of cells) and not with cellular hyperplasia (that is, an increase in the number of cells). Similarly, between days 15 and 18, the more than twofold decrease in the size of the corpus luteum was associated with a 2.7 -fold decrease in cell protein:DNA ratio but only a $20 \%$ decrease in DNA content. Thus, during early growth (days 2-4) and regression (days 15-18) of the pig corpus luteum, changes in the size of the corpus luteum appear to be primarily a consequence of changes in the size of cells rather than changes in the number of cells. In contrast, from day 4 to day 15 , growth of the pig corpus luteum was associated primarily with increased DNA content, indicating continued hyperplasia, but little or no change in the protein:DNA ratio.

This pattern of growth is in contrast to those observed in corpora lutea from cows and sheep (Jablonka-Shariff et al.,
1993; Zheng et al., 1994; Reynolds et al., 1994; Reynolds and Redmer, 1999). In both cows and sheep, luteal growth depends primarily on changes in the number of cells and not on changes in the size of cells. Furthermore, in corpora lutea from cows and sheep, the ratio of protein:DNA remains constant throughout the oestrous cycle until it decreases in association with luteal regression (Jablonka-Shariff et al., 1993; Zheng et al., 1994). However, the protein:DNA ratio only provides an indication of the average size of cells, and these data should therefore be interpreted with this in mind. In sheep, for example, although the overall size of cells does not change, the size of the large luteal cells, which represent $11 \%$ of the total number of cells, increases by threefold; conversely, the size of the non-steroidogenic cells (fibroblasts, endothelial cells and pericytes), which represent $68 \%$ of the total number of cells, decreases by 1.2- to 2-fold (Farin et al., 1986). Nevertheless, the results of the present study indicate that an increase in the average size of cells is an important component of early luteal growth in pigs but not in cows and sheep.

Assuming that there is a constant amount of DNA per nucleus ( $~ 6.2$ pg; Baserga, 1985; Reynolds et al., 1990), the total number of cells per corpus luteum was approximately $67,97,150,155,203$ and $163 \times 10^{6}$ on days $2,4,8,12,15$ and 18 , respectively. Therefore, on the basis of the labelling index and the estimated number of cells per corpus luteum, the total number of cells per corpus luteum that were synthesizing DNA remained relatively constant throughout the oestrous cycle, and was $35,38,33,27,32$ and $30 \times 10^{6}$ per day on days $2,4,8,12,15$ and 18 , respectively. This pattern of cellular proliferation also differs from those of cows and sheep, in which significant increases in the total number of proliferating cells occur early in the oestrous cycle (JablonkaShariff et al., 1993; Zheng et al., 1994; Reynolds and Redmer, 1999).

The pig corpus luteum also contains a substantial number of proliferating cells during luteal regression, which is not observed in either cows or sheep (Jablonka-Shariff et al., 1993; Zheng et al., 1994; Reynolds and Redmer, 1999). A portion of this sustained high rate of cell proliferation may be due to cell turnover in the portion of the luteal vasculature that is maintained during luteal regression. In addition, it may be due to an increased content of fibroblasts in association with resorption of the luteal parenchymal tissue and increased fibrous tissue content of the regressing corpus luteum (Reynolds et al., 1994; Reynolds and Redmer, 1999). However, such high rates of cell proliferation are not observed during luteal regression in other species that show similar morphological changes during luteal regression (Jablonka-Shariff et al., 1993; Zheng et al., 1994; Reynolds and Redmer, 1999).

Studies in which morphometric techniques were used to evaluate luteal development in several species demonstrated that corpora lutea undergo dynamic changes in cellular composition throughout the oestrous cycle (Parry et al., 1980; Niswender et al., 1985; Farin et al., 1986,1989; Schwall et al., 1986; Lei et al., 1991; Wiltbank and Niswender, 1992). On the basis of histological observations of mitotic figures in ovine and bovine corpora lutea, it was suggested that steroidogenic luteal cells proliferate only early in the oestrous cycle 
(McClellan et al., 1975; O'Shea et al., 1980, 1986). However, the present study and several other studies have demonstrated that at least a few steroidogenic cells proliferate throughout most of the oestrous cycle (Priedkalns et al.,1968; Jablonka-Shariff et al., 1993; Zheng et al., 1994; Reynolds and Redmer, 1999), albeit at a relatively low rate, especially after mid-cycle.

The observation that a large proportion of the proliferating cells in the pig corpus luteum are endothelial cells is consistent with data from other species. In rats, the greatest labelling index of luteal endothelial cells (26-36\%) was observed within 7-24 h after ovulation, but the labelling index remained relatively high $(2-4 \%)$ at the later stages of luteal development (Gaede et al., 1985; Meyer and McGeachie, 1988). More recent studies have confirmed that a major portion of the proliferating luteal cells in cows, rats, primates and sheep are endothelial cells (Jablonka-Shariff et al., 1993; Zheng et al., 1994; Christenson and Stouffer, 1996). These observations are not unexpected because, by midcycle, endothelial cells form $\geq 50 \%$ of the cells of the mature corpus luteum (Farin et al., 1986; Lei et al., 1991; Reynolds and Redmer, 1999).

During its rapid growth phase, the corpus luteum of domestic animals shows dynamic structural and functional changes that must be tightly regulated to ensure normal growth and development (Baserga, 1985; Reynolds et al., 1992, 1994; Redmer and Reynolds, 1996; Reynolds and Redmer, 1999). After ovulation, the corpus luteum is formed from the granulosa and thecal cells of the ruptured follicle (Zheng et al., 1993; Reynolds et al., 1994; Redmer and Reynolds, 1996; Reynolds and Redmer, 1999). Thecal invasion brings with it a host of blood vessels and proliferating endothelial cells, and the number of these nonsteroidogenic cells increases continually (Reynolds and Redmer, 1999). These observations are consistent with the present study, in which most of the proliferating cells during early and mid-cycle were endothelial cells. As a result of this rapid endothelial proliferation and vascular growth, the steroidogenic cells were closely associated with capillaries by mid-cycle. These observations are similar to reports for corpora lutea of several other species (Dharmarajan et al., 1985; Zheng et al., 1993; Jablonka-Shariff et al., 1994; Reynolds et al., 1994; Redmer and Reynolds, 1996) and highlight the importance of angiogenesis in normal luteal growth and development (Redmer and Reynolds, 1996; Reynolds and Redmer, 1999).

The authors wish to thank Kim C. Kraft and James D. Kirsch for their expert technical assistance, and Timothy Johnson and Ronald C. Zimprich for assistance with animal care. Supported, in part, by a competitive grant (93-37203-9271) from the NRI-CGP, USDA.

\section{References}

Andersen DH (1926) Lymphatics and blood vessels of the ovary of the sow Contributions to Embryology 88 109-123

Baserga R (1985) The Biology of Cell Reproduction Harvard University Press, Cambridge

Bassett DL (1943) The changes in the vascular pattern of the ovary in the albino rat during the estrous cycle American Journal of Anatomy 73 251-291

Bruce NW and Moor RM (1976) Capillary blood flow to ovarian follicles, stroma and corpora lutea of anaesthetized sheep Journal of Reproduction Fertility 46 299-304

Cavazos LF, Anderson LL, Belt WD, Henricks DM, Kraeling RR and Melampy RM (1969) Fine structure and progesterone levels in the corpus luteum of the pig during the estrous cycle Biology of Reproduction 183-106

Christenson LK and Stouffer RL (1996) Proliferation of microvascular endothelial cells in the primate corpus luteum during the menstrual cycle and simulated early pregnancy Endocrinology 137 367-374

Clark JG (1900) The origin, development and degeneration of the blood vessels of the human ovary Joins Hopkins Hospital Reports 9593-676

Conley AJ and Ford SP (1991) Effects of $\mathrm{PGF}_{2 \alpha}$ on pig corpora lutea following administration on day 9 of the estrous cycle Animal Reproduction Science $\mathbf{2 4}$ 335-342

Conley AJ, Kaminski MA, Dubowsky SA, Jablonka-Shariff A, Redmer DA and Reynolds LP (1995) Immunohistochemical localization of 3Bhydroxysteroid dehydrogenase and P450 17 $\alpha$-hydroxylase during follicular and luteal development in pigs, sheep and cows Biology of Reproduction 52 $1081-1094$

Dharmarajan AM, Bruce NW and Meyer GT (1985) Qualitative ultrastructural characteristics relating to transport between luteal cell cytoplasm and blood in the corpus luteum of the pregnant rat American Journal of Anatomy $17287-99$

Farin CE, Moeller CL, Sawyer HR, Gamboni F and Niswender GD (1986) Morphometric analysis of cell types in the ovine corpus luteum throughout the estrous cycle Biology of Reproduction 35 1299-1308

Farin CE, Nett TM and Niswender GD (1989) Effects of luteinizing hormone on luteal cell populations in hypophysectomized ewes Journal of Reproduction and Fertility 88 61-70

Fricke PM, Al-Hassan MJ, Roberts AJ, Reynolds L, Redmer D and Ford JJ (1997) Effect of gonadotropin treatment on size, number and cell proliferation of antral follicles in cows Domestic Animal Endocrinology 14 171-180

Gaede SD, Sholley MM and Quattropawi SL (1985) Endothelial mitosis during the initial stages of the corpus luteum neovascularization in the cycling adult rat American Journat of Anatomy 172 173-180

Garverick HA and Smith MF (1986) Mechanisms associated with subnormal luteal function Journal of Animal Science 62 Supplement 2 92-105

Gore-Langton RE and Armstrong DT (1994) Follicular steroidogenesis and its control. In The Physiology of Reproduction pp 571-576 Eds E Knobil and JD Neill. Raven Press, New York

Hansel W (1981) Plasma hormone concentrations associated with early embryo mortality in heifers Journal of Reproduction and Fertility Supplement $30231-239$

Jablonka-Shariff A, Fricke PM, Kraft KC, Reynolds LP and Redmer DA (1992) Bromodeoxyuridine (BrdU) immunohistochemistry to evaluate labeling index of tissue in vivo. In Handbook of Methods for Study of Reproductive Physiology in Domestic Animals Section VII D Eds PJ Dziuk and MB Wheeier. Univesity of Illinois, Urbana

Jablonka-Shariff A, Grazul-Bilska AT, Redmer DA and Reynolds LP (1993) Growth and cellular proliferation of ovine corpora lutea throughout the ovine estrous cycle Endocrinology 133 1871-1879

Jablonka-Shariff A, Fricke PM, Grazul-Bilska AT, Reynolds LP and Redmer DA (1994) Size, number, cellular proliferation and atresia of gonadotropininduced follicles in ewes Biology of Reproduction 51 531-540

Jablonka-Shariff A, Grazul-Bilska AT, Redmer DA and Reynolds LP (1997) Cellular proliferation and fibroblast growth factors in the corpus luteum during early pregnancy in ewes Growth Factors 14 15-23

Jin L, Reynolds LP, Redmer DA, Caton JS and Crenshaw JD (1994) Effects of dietary fiber on intestinal growth, cell proliferation, and morphology in growing pigs fournal of Animal Science 72 2270-2278

Lei ZM, Chegini N and Rao ChV (1991) Quantitative cell composition of human and bovine corpora lutea from various reproductive states Biology of Reproduction 44 1148-1156

Lin P and Allison DC (1993) Measurement of DNA content and tritiated thymidine and bromodeoxyuridine incorporation by the same cells Journal of Histochemistry and Cytochemistry 41 1435-1439

Lowry OH, Rosebrough NJ, Farr AL and Randall RJ (1951) Protein measurement with the folin phenol reagent Journal of Biological Chemistry $193265-275$

Luna LG (1968) Manual of Histolgical Staining Methods of the Armed Forces Institute of Pathology McGraw-Hill, New York

McClellan MC, Diekman MA, Abel JH, Jr and Niswender GD (1975) Luteinizing hormone, progesterone and the morphological development of 
normal and superovulated corpora lutea in sheep Cell and Tissue Research 164 291-307

Masuda H, Anderson LL, Henricks DM and Melampy RM (1966) Progesterone in ovarian venous plasma and corpora lutea of the pig Endocrinology 80 240-246

Meyer GT and McGeachie JK (1988) Angiogenesis in the developing corpus luteum of pregnant rats: a stereologic and autoradiographic study Anatomical Record 222 18-25

Moss S, Wrenn TR and Sykes JF (1954) Some histological and histochemical observations of the bovine ovary during the oestrous cycle Anatomical Record 120 409-433

Niswender GD and Nett TM (1988) The corpus luteum and its control. In The Physiology of Reproduction pp 489-525 Eds E Knobil and JD Neill. Raven Press, New York

Niswender GL, Schwall RH, Fitz TA, Farin CE and Sawyer HR (1985) Regulation of luteal function in domestic ruminants: new concepts Recent Progress in Hormone Research 41 101-142

O'Shea JD, Cran DG and Hay MF (1980) Fate of the theca interna following ovulation in the ewe Cell and Tissue Research 210 305-319

O'Shea JD, Rodgers RJ and Wright PJ (1986) Cellular composition of the sheep corpus luteum in the mid-and late luteal phases of the oestrous cycle Journal of Reproduction and Fertility 76 685-691

Parry DM, Willcox DL and Thorbun GD (1980) Ultrastructural and cytochemical study of the bovine corpus luteum Journal of Reproduction and Fertility 60 340-357

Priedkalns J, Weber AF and Zemjanis R (1968) Qualitative and quantitative morphological studies of the cells of the membrana granulosa, theca interna and corpus luteum of the bovine ovary Zeitschrift fur Zellforschung 85 501-520

Redmer DA and Reynolds LP (1996) Angiogenesis in the ovary Reviews of Reproduction 1 182-192

Redmer DA, Kirsch JD and Reynolds LP (1991) Production of mitogenic factors by cell types of bovine large estrogen-active and estrogen-inactive follicles Journal of Animal Science $69237-245$

Reynolds LP (1986) Utero-ovarian interaction during early pregnancy: role of conceptus-induced vasodilation Journal of Animal Science $\mathbf{6 2}$ Supplement 2 $47-61$

Reynolds LP and Ford SP (1984) Contractility of the ovarian vascular bed during the oestrous cycle and early pregnancy in gilts Journal of Reproduction and Fertility $7165-71$

Reynolds LP and Redmer DA (1998) Expression of the angiogenic factors, basic fibroblast growth factor (bFGF) and vascular endothelial growth factor (VEGF), in the ovary Journal of Animal Science 76 1671-1681

Reynolds LP and Redmer DA (1999) Growth and development of the corpus luteum Journal of Reproduction and Fertility Supplement 54 179-189

Reynolds LP, Millaway DS, Kirsch JD, Infeld JE and Redmer DA (1990) Growth and in vitro metabolism of placental tissues of cows from day 100 to day 250 of gestation Journal of Reproduction and Fertility 89 213-222

Reynolds LP, Killilea SD and Redmer DA (1992) Angiogenesis in the female reproductive system $F A S E B$ Journal $6886-892$

Reynolds LP, Grazul-Bilska AT, Killilea SD and Redmer DA (1994) Mitogenic factors of corpora lutea Progress in Growth Factor Research 5 159-175

SAS (1985) Statistical Analysis System Users Guide 5th Edn SAS Institute, Raleigh, NC

Schutte B, Reynders MJ, Bosman FT and Blijham GH (1987) Studies with anti-bromodeoxyuridine antibodies II. Simultaneous immunocytochemical detection of antigen expression and DNA synthesis by in vivo labeling of mouse intestinal mucosa Journal of Histochemistry and Cytochemistry 35 $371-374$

Schwall RH, Sawyer HR and Niswender GD (1986) Changes in the distribution of sizes of ovine luteal cells during the estrous cycle Biology of Reproduction 34 911-918

Shepro D and D'Amore PA (1984) Physiology and biochemistry of the vascular wall endothelium. In Handbook of Physiology, Section 2: Cardiovascular System, Vol. IV Microcirculation Part 1 pp 103-164 Eds EM Renkin and CC Michel. Waverly Press, Baltimore

Taraska T, Reynolds LP and Redmer DA (1989) In vitro secretion of angiogenic activity by ovine follicles. In Growth Factors and the Ovary $\mathrm{pP}$ 267-272 Ed. AN Hirshfield. Plenum Press, New York

Wiltbank MC and Niswender GD (1992) Functional aspects of differentiation and degeneration of the steroidogenic cells of the corpus luteum in domestic ruminants Animal Reproduction Science 28 103-110

Zheng J, Redmer DA and Reynolds LP (1993) Vascular development and heparin-binding growth factors in the bovine corpus luteum at several stages of the estrous cycle Biology of Reproduction 49 1177-1189

Zheng J, Fricke PM, Reynolds LP and Redmer DA (1994) Evaluation of growth, cell proliferation and cell death in bovine corpora lutea throughout the estrous cycle Biology of Reproduction 51 623-632 